\section{Environmental Consequences of Efficient Use of Nitrogen Fertilizers}

\author{
Gheorghe Ciobanu - Cornelia Ciobanu - \\ Cornel Domuta - Nicolae Csep - Petru Burescu
}

Agricultural Research Station Oradea-Romania
Nitrogen fertilizer represents major economic burden. For this reason, although the efficiency of nitrogen utilization varies highly, its actual use generally remains at low levels; these averaging between 25 and 50\%. We set up an experiment at the Oradea Research Station, using ${ }^{15} \mathrm{~N}$ labeled fertilizers, in order to investigate the possibility of increasing $N$ fertilizer efficiency in winter wheat under irrigation conditions.

Fertilizers labeled with ${ }^{15} \mathrm{~N}$ allows us to individually determine its effect on yield formation, as well as the use efficiency of $N$ from fertilizer following application rate and time. The amount of $N$ derived from fertilizer as determined in straw and grain yield is high. When the labeled fertilizer is applied at tillering time, the values of this indicator rise when higher $N$ levels we applied.

In separate experiments, we investigated a series of aspects connected to chemical fertilizer regarding the determination of the type of fertilizer, optimum time and rates of application; all these as a function of the special pedoclimatic conditions.

The results obtained in the field show that the effectiveness of $N$ utilization in wheat is most variable and generally low, often ranging between 25 and 33\%, owing to $N$ loss within the system through leaching and $\mathrm{NH}_{3}$ volatilization.

A readily achievable increase in efficiency of 5 percentage points would result in considerable savings, and can be brought about by reducing nitrogen losses. The added benefits to the environment in terms of reduced ground/water contamination and lowered nitrous oxide $\left(N_{20}\right)$ emissions would also be substantial.

The figures for $N$ fertilizer use efficiency (\% $N$ range from 35.5 to 72.6, the highest value being recorded with an $N$ application of $120 \mathrm{~kg} / \mathrm{ha}$ at tillering, when the previous crop was sunflower).

\section{INTRODUCTION}

In Romania, there is a vast network of research stations under the coordination of the Research Institute for Cereals and Industrial Crops. Long-term stationary field experiment have been set up study the effect of chemical and organic fertilizers on yields of main crops and their quality, with one eye on soil fertility evolution over the long-terms.

The study of issues related using these fertilizers as rationally as possible may be successfully carried out in field experiments, especially by using stable and radioactive isotopes (Lazányi, 1997, 1998; Lazányi and Vágvölgyi, 1999).

The results obtained during continuous experimentation revealed that fact that $\mathrm{N}$ use efficiency in the fertilizers containing this element used on wheat crops, varied between 48 and $90 \%$, on Fundulea chernozem (Hera, 1971), between 50 and $87 \%$ on the luvical brown soil around Oradea, and between 26 and $50 \%$ on the luvic soil in the area aroun Beius.

In order to obtain practical information, to raise the use efficiency of the active substance in phosphorus and $\mathrm{N}$ fertilizers used on wheat crops, an important research program based on stable and radioactive isotopes has been initiated, coordinated by the Mixed Division FAO/IEA. Fundulea and other stations belonging to this institute also joined the program. In resorting to isotope research, the scientists focused on the influence of the methods and the application time of such $\mathrm{N}$ fertilizers as ammonium sulphate and urea on wheat yield and quality (Hera et al., 1984a; Hera et al., 1984b; Ciobanu et al., 1995).

In order to investigate the possibility of increasing $\mathrm{N}$ fertilizer efficiency in winter wheat under irrigation conditions, an experiment was set up on the experimental field of the Agricultural Research Station of Oradea, Romania.

In the present study, by using the ${ }^{15} \mathrm{~N}$ stable isotope to label the fertilizers, we examined the influence of the previous plant and the application times of the fertilizers on the use efficiency of the active substance, under irrigation conditions, on the brown soil around Oradea.

\section{MATERIALS AND METHODS}

This experiment was organized within a program financed by the International Atomic Energy Agency in Vienna, focusing on the differentiation of $\mathrm{N}$ use efficiency, depending on pedoclimatic conditions and the application time and rate of fertilizers.

The experiment was held under irrigation conditions, on a medium brown soil, supplied with the main nutritive elements, using the ${ }^{15} \mathrm{~N}$ atom stable isotope as a labeled element. Urea with an excess of ${ }^{15} \mathrm{~N}$ was used as a standard fertilizer. The fertilizers doses used were (Table 1):

- $\mathrm{N}_{0}$ unfertilized variant;

- $\mathrm{N}_{0.5} \mathrm{~N}_{60}$ (N rate equivalent to $50 \%$ of the optimum rate);

- $\mathrm{N}_{1.0} \quad \mathrm{~N}_{120}$ (the must propitious $\mathrm{N}$ dose $100 \%$ of the optimum rate);

- $\mathrm{N}_{1.5} \mathrm{~N}_{180}(150 \%$ of the optimum rate).

When the previous plant was pea, the $\mathrm{N}$ doses were $\mathrm{N}_{40} ; \mathrm{N}_{80} ; \mathrm{N}_{120}$. All the tested variants were uniformly fertilized with $120 \mathrm{~kg}$ of $\mathrm{P}_{2} \mathrm{O}_{5} /$ ha and 80 $\mathrm{kg}$ of $\mathrm{K}_{2} \mathrm{O} / \mathrm{ha}$, at sowing time. The $\mathrm{N}$ fertilizers were applied in 2 phases: $1 / 3$ of the total dose at sowing time $\left(\mathrm{x}_{1}\right)$ and $2 / 3$ of the dose in springtime at tillering $\left(\mathrm{x}_{2}\right)$. 
Table 1: Experimental design

\begin{tabular}{|c|r|r|}
\hline $\begin{array}{c}\text { Rate of N } \\
\text { kg/ha }\end{array}$ & $\begin{array}{c}\text { Applied in autumn } \\
\text { at sowing }\end{array}$ & \multicolumn{2}{|c|}{$\begin{array}{c}\text { Applied in spring } \\
\text { at tillering }\end{array}$} \\
\hline $\mathrm{N}_{0}$ & 0 & 0 \\
\hline $\mathrm{N}-0.5$ & $20^{*}$ & 40 \\
$\mathrm{~N}$ & 20 & $40^{*}$ \\
\hline & $40^{*}$ & 80 \\
$\mathrm{~N}-1.0$ & 40 & $80^{*}$ \\
\hline $\mathrm{N}-1.5$ & $60^{*}$ & 120 \\
& 60 & $120^{*}$ \\
\hline
\end{tabular}

${ }^{* 15} \mathrm{~N}$-was applied

An irrigating system was used to maintain a humidity in the soil proper to $75 \%$ of the field capacity on a $0-50 \mathrm{~cm}$ soil layer. The evolution of the soil humidity was established by performance every 7 to 10 days, to $120 \mathrm{~cm}$ depth. Soil moisture was determined with a neutron probe, via access tubes on each plot.

The previous plants used over the three experimental years were corn for its grains (in 1995), pea (in 1996) and sunflower (in 1997).

The same amount of water was applied to all the plots, being calculated according to the necessities of the fertilized variants at the must propitious $\mathrm{N}$ rate (120 kg/ha).

The soil and plant tests regarding the content of the nitrogen labeled ${ }^{15} \mathrm{~N}$ were performed in the laboratory of the International Agency for Atomic Energy in Vienna.

The following determinations and calculations appropriate to ${ }^{15} \mathrm{~N}$ experiments were performed:

Determinations

- D.M kg/ha yield; the whole plant and its components;

- the total ${ }^{15} \mathrm{~N}$ content $(\%)$ of the dry matter;

- ${ }^{15} \mathrm{~N}$ abundance (\%) in the plant;

- ${ }^{15} \mathrm{~N}$ abundance (\%) in the $\mathrm{N}$ fertilizers used.

Calculations

- $\%{ }^{15} \mathrm{~N}$ excess;

- $\%{ }^{15} \mathrm{~N}$ abundance in the sample (natural abundance: $\left(0,3663\right.$ atom $\left.\%{ }^{15} \mathrm{~N}\right)$;

- $\quad$.d.f.f. $\%=\mathrm{N}(\%)$ derived from fertilizers $=\left(\%{ }^{15} \mathrm{~N}\right.$ excess atom in plant $) /\left(\%{ }^{15} \mathrm{~N}\right.$ excess atom in fertilizer);

- $\mathrm{N}$ (total) exported $(\mathrm{kg} / \mathrm{ha})$;

- $\mathrm{N}$ derived from fertilizer $(\mathrm{kg} / \mathrm{ha})$;

- $\mathrm{N}$ use efficiency in fertilizer (\%).

\section{RESULTS}

The total amount of $\mathrm{N}$ exported through the wheat yield: The grain and straw yields produced over the three experimental years in wheat crop under irrigation conditions were mainly influenced, by the applied fertilizer rates and partially by the previous plant (due to the differences between the fertilizer rates).

During the agricultural year 1995-1996, when the previous plant was pea, smaller rates were used, the maximum being of $120 \mathrm{~kg} \mathrm{~N} / \mathrm{ha}$ and the weather conditions did not allow the wheat crop to grow; there was a slightly inferior yield, as opposed to when corn was used as the previous plant. But increases up to $4.5 \mathrm{q} / \mathrm{ha}$ grains and $7.0 \mathrm{q} / \mathrm{ha}$ straw were recorded, as compared to 1996-1997, when sunflower was the previous plant.

Over the three experimental years, yield levels were directly linked to the amount of $\mathrm{N}$ dose used, both in grains and in wheat straw.

The maximum yield benefits calculated for $1 \mathrm{~kg}$ s.a., with grains as well as with straws, were achieved, regardless of the previous plant, by applying a fertilizer rate of $60 \mathrm{~kg} / \mathrm{ha}$ after corn, and $40 \mathrm{~kg} / \mathrm{ha}$ after pea (Table 2). The yield differences between the minimum and the most propitious doses are constant enough (aprox. $11.0 \mathrm{q} /$ ha grains and 11.2 $\mathrm{q} /$ ha straws, when the previous plant is corn and the sunflower and $7.4 \mathrm{q} /$ ha grains and $11.4 \mathrm{q} /$ ha straws when the previous plant is pea). When doses are increased from the most propitious level to the maximum one, the greatest yield benefit in grains, $8.1 \mathrm{q} / \mathrm{ha}$, can be obtained when the previous plant is sunflower, implying in this case the idea of increasing the maximum $\mathrm{N}$ rate above this level under irrigation conditions.

The $\mathrm{N}$ content $(\mathrm{N} \%)$ of the grain and straw yield is strongly differentiated according to the previous plant and application rate (Table 2). Thus, that the $\mathrm{N} \%$ in the wheat grains is ranges between $1.75 \%$ and $2.27 \%$ after corn and between 2.17 and $2.51 \%$ after the pea and $2.13 \%$ after the sunflower. The greatest differences concerning $\mathrm{N} \%$ content of the wheat grains, according to the previous plant, either occur among the unfertilized variants or, with the fertilized ones, with a minimum 2 rate.

As far as $\mathrm{N} \%$ content of the straws is concerned, this indicator increased from $0.46 \%$ to $0.72 \%$, according to $\mathrm{N}$ application rates when the previous plant was corn. When the previous plant was pea or sunflower, the values of the $\mathrm{N}$ content in straws were much lower than when the previous plant was corn. They are uniform in all fertilizing variants.

The total $\mathrm{N}$ amount $(\mathrm{kg} / \mathrm{ha})$ in the soil and fertilizer absorbed by the plant and calculated according to the obtained yields and to their $\mathrm{N}$ content, reveals great differences according to the previous plant and the $\mathrm{N}$ dose application rate.

The total $\mathrm{N}$ uptake through the grain and straw yield ranges between 88.5 and $211.9 \mathrm{~kg} / \mathrm{ha}$ after corn, between 93.2 and $193.9 \mathrm{~kg} / \mathrm{ha}$ after pea, and between 62.0 and $158.9 \mathrm{~kg} / \mathrm{ha}$ after sunflower (Table 2). The large amount of total $\mathrm{N}$ exported through the wheat crop is larger when the previous plant was pea then when the wheat was cultivated after sunflower. 
Table 2: Influence of fertilizer-N levels on wheat yield, $\mathrm{N} \%$ yield content and $\mathrm{N}$ uptake by plant at harvest

\begin{tabular}{|c|c|c|c|c|c|c|c|c|c|}
\hline \multirow{2}{*}{ Time } & \multirow{2}{*}{$\begin{array}{c}\text { Treatment } \\
\text { N level }\end{array}$} & \multicolumn{3}{|c|}{ Yield (q/ha) } & \multicolumn{2}{|c|}{ N\% content } & \multicolumn{3}{|c|}{ N uptake (kg/ha) } \\
\hline & & Grain & Straw & Total & Grain & Straw & Grain & Straw & Total \\
\hline \multirow{4}{*}{ 1994-1995 } & $\mathrm{N}_{0}$ & 38.7 & 45.3 & 84.0 & 1.75 & 0.46 & 67.71 & 20.84 & 88.55 \\
\hline & $\mathrm{N}_{0.5}$ & 52.3 & 62.4 & 114.7 & 1.95 & 0.47 & 101.98 & 29.33 & 131.31 \\
\hline & $\mathrm{N}_{1.0}$ & 61.4 & 73.4 & 134.8 & 2.08 & 0.64 & 127.71 & 46.98 & 174.69 \\
\hline & $\mathrm{N}_{1.5}$ & 67.5 & 81.5 & 149.0 & 2.27 & 0.72 & 153.22 & 58.68 & 211.90 \\
\hline \multirow{4}{*}{ 1995-1996 } & $\mathrm{N}_{0}$ & 36.2 & 44.3 & 80.5 & 2.17 & 0.33 & 78.55 & 14.62 & 93.17 \\
\hline & $\mathrm{N}_{0.5}$ & 51.2 & 61.0 & 112.2 & 2.21 & 0.32 & 113.15 & 19.52 & 132.67 \\
\hline & $\mathrm{N}_{1.0}$ & 58.6 & 71.4 & 130.0 & 2.24 & 0.33 & 131.26 & 23.56 & 154.82 \\
\hline & $\mathrm{N}_{1.5}$ & 66.2 & 79.5 & 145.7 & 2.51 & 0.35 & 166.16 & 27.82 & 193.98 \\
\hline \multirow{4}{*}{ 1996-1997 } & $\mathrm{N}_{0}$ & 34.5 & 36.5 & 71.0 & 1.47 & 0.31 & 50.71 & 11.31 & 62.02 \\
\hline & $\mathrm{N}_{0.5}$ & 44.6 & 53.5 & 98.1 & 1.86 & 0.36 & 82.96 & 19.26 & 102.22 \\
\hline & $\mathrm{N}_{1.0}$ & 53.6 & 61.7 & 115.3 & 1.92 & 0.38 & 102.91 & 23.45 & 126.36 \\
\hline & $\mathrm{N}_{1.5}$ & 61.7 & 72.5 & 134.2 & 2.13 & 0.38 & 131.42 & 27.55 & 158.97 \\
\hline
\end{tabular}

The $\mathrm{N}$ amount uptake by plants from the fertilizer: According to the analyses concerning the ${ }^{15} \mathrm{~N}$ content in grains and straws, the amount of $\mathrm{N}$ from the fertilizers and contained in the yield was calculated using yields obtained every year. Analyzing the data presented in Table 3, note the great differences regarding the $\mathrm{N}$ amount derived from the fertilizers. These differences may occur by yield and previous plant. Thus, in 1995, when the previous plant was the corn, this index ranges between 12.0 and $57.6 \mathrm{~kg} \mathrm{~N} / \mathrm{ha}$ in grains and between 2.8 and $14.9 \mathrm{~kg} \mathrm{~N} / \mathrm{ha}$ straws, the total values varying between 14.8 and $72.5 \mathrm{~kg} \mathrm{~N} / \mathrm{ha}$.

In 1996, when the previous plant was pea, the $\mathrm{N}$ amount derived from fertilizers and contained in grains ranges between 10.0 and $36.7 \mathrm{~kg} \mathrm{~N} / \mathrm{ha}$. That contained in straws ranges between 1.3 and $6.1 \mathrm{~kg}$ $\mathrm{N} / \mathrm{ha}$, and the whole plant contain an amount of $\mathrm{N}$ ranging between 11.3 and $42.8 \mathrm{~kg} \mathrm{~N} / \mathrm{ha}$.

In 1997, when the previous plant was sunflower, the wheat yield containing the largest $\mathrm{N}$ amount derived from fertilizers, namely: between 30.8 and $92.7 \mathrm{~kg} \mathrm{~N} / \mathrm{ha}$ in grains and between 4.8 and $15.9 \mathrm{~kg}$ $\mathrm{N} /$ ha in straws. The whole plant containing an amount of $\mathrm{N}$ derived from the applied fertilizers between 20.56 and $74.63 \mathrm{~kg} \mathrm{~N} / \mathrm{ha}$. The differences between these values could be due to the previous plant and to the fertilizer application rate.

Analyzing the current data, we observe that over the three experimental years, when the fertilizers were applied in spring at plant tillering, the $\mathrm{N}$ amount derived from fertilizers and contained in the wheat yield is much higher than in the autumn application. Thus, in 1995, in the autumn application (Table 4), the $\mathrm{N}$ amount derived from the fertilizers in the wheat grains ranges between 2.7 and $13.7 \mathrm{~kg} \mathrm{~N} / \mathrm{ha}$, and in straws between 0.8 and $4.7 \mathrm{~kg} \mathrm{~N} / \mathrm{ha}$, according to the fertilizer application rate. In the spring application, these values ranges between 9.3 and 43.9 $\mathrm{kg} \mathrm{N} / \mathrm{ha}$ in grains and 2.0 and $10.2 \mathrm{~kg} \mathrm{~N} / \mathrm{ha}$ in straws.

The same aspect is recorded during the other two
Table 3: The relation between fertilizers- $\mathrm{N}$ levels and $\mathrm{N}$ uptake by plant from fertilizer

\begin{tabular}{|c|c|r|r|r|}
\hline \multirow{4}{*}{ Time } & \multirow{2}{*}{$\begin{array}{c}\text { N treatment } \\
\text { (kg/ha) }\end{array}$} & \multicolumn{3}{|c|}{ N uptake from fertilizer } \\
\cline { 2 - 5 } & $\mathrm{N}_{60}$ & 12.0 & 2.8 & 14.8 \\
\hline \multirow{4}{*}{$1994-1995$} & $\mathrm{~N}_{120}$ & 32.2 & 9.8 & 42.0 \\
\cline { 2 - 5 } & $\mathrm{N}_{180}$ & 57.6 & 14.9 & 72.5 \\
\hline \multirow{3}{*}{$1995-1996$} & $\mathrm{~N}_{40}$ & 10.0 & 1.3 & 11.3 \\
\cline { 2 - 5 } & $\mathrm{N}_{80}$ & 24.7 & 4.4 & 29.1 \\
\cline { 2 - 5 } & $\mathrm{N}_{120}$ & 36.7 & 6.1 & 42.8 \\
\hline \multirow{3}{*}{$1996-1997$} & $\mathrm{~N}_{60}$ & 30.8 & 4.8 & 35.6 \\
\cline { 2 - 5 } & $\mathrm{N}_{120}$ & 43.2 & 10.8 & 54.0 \\
\cline { 2 - 5 } & $\mathrm{N}_{180}$ & 92.7 & 15.9 & 108.6 \\
\hline \multirow{3}{*}{$\begin{array}{c}\text { Average } \\
\text { 1994-1997 }\end{array}$} & $\mathrm{N}_{0.5}$ & 17.60 & 2.96 & 20.56 \\
\cline { 2 - 5 } & $\mathrm{N}_{1.0}$ & 33.36 & 8.33 & 41.70 \\
\cline { 2 - 5 } & $\mathrm{N}_{1.5}$ & 62.33 & 12.31 & 74.63 \\
\hline
\end{tabular}

experimental years (Table 4). In 1996, the total amount of $\mathrm{N}$ contained in plants ranged between 3.3 and $15.8 \mathrm{~kg} \mathrm{~N} / \mathrm{ha}$ when the $\mathrm{N}$ fertilizers were applied in autumn and between 8.0 and $27.0 \mathrm{~kg} \mathrm{~N} / \mathrm{ha}$ when they were applied in spring. In 1997, the total amount of $\mathrm{N}$ contained in plants ranged between 8.7 and 21.4 $\mathrm{kg} \mathrm{N} / \mathrm{ha}$ in the autumn application and between 26.9 and $87.2 \mathrm{~kg} \mathrm{~N} / \mathrm{ha}$ in the spring application.

That the smallest $\mathrm{N}$ amount in plants derived from fertilizers are recorded in 1996 when the previous plant was pea and the largest in 1997 when the previous plant was sunflower. 
Table 4: The relationship between $\mathbf{N}$ uptake from fertilizer and time of fertilizer application

\begin{tabular}{|c|c|c|c|c|c|}
\hline Time & $\mathbf{N}$ & $\begin{array}{c}\text { N treatment } \\
(\mathrm{kg} / \mathrm{ha})\end{array}$ & $\begin{array}{c}\text { Applied at } \\
\text { sowing }\end{array}$ & $\begin{array}{c}\text { Applied at } \\
\text { tillering }\end{array}$ & $\begin{array}{c}\text { N uptake from } \\
\text { fertilizer }\end{array}$ \\
\hline \multirow{9}{*}{ 1994-1995 } & \multirow{3}{*}{$\mathrm{N}_{60}$} & Grain & 2.7 & 9.3 & 12.0 \\
\hline & & Straw & 0.8 & 2.0 & 2.8 \\
\hline & & Total & 3.5 & 11.3 & 14.8 \\
\hline & \multirow{3}{*}{$\mathrm{N}_{120}$} & Grain & 8.3 & 23.9 & 32.2 \\
\hline & & Straw & 2.3 & 7.5 & 9.8 \\
\hline & & Total & 10.6 & 21.4 & 42.0 \\
\hline & \multirow{3}{*}{$\mathrm{N}_{180}$} & Grain & 13.7 & 43.9 & 57.6 \\
\hline & & Straw & 4.7 & 10.2 & 14.9 \\
\hline & & Total & 18.4 & 54.1 & 72.5 \\
\hline \multirow{9}{*}{$1995-1996$} & \multirow{3}{*}{$\mathrm{N}_{40}$} & Grain & 2.8 & 7.2 & 10 \\
\hline & & Straw & 0.5 & 0.8 & 1.3 \\
\hline & & Total & 3.3 & 8.0 & 11.3 \\
\hline & \multirow{3}{*}{$\mathrm{N}_{80}$} & Grain & 6.2 & 18.5 & 24.7 \\
\hline & & Straw & 1.6 & 2.8 & 4.4 \\
\hline & & Total & 7.8 & 21.3 & 29.1 \\
\hline & \multirow{3}{*}{$\mathrm{N}_{180}$} & Grain & 13.4 & 23.3 & 36.7 \\
\hline & & Straw & 2.4 & 3.7 & 6.1 \\
\hline & & Total & 15.8 & 27.0 & 42.8 \\
\hline \multirow{9}{*}{ 1996-1997 } & \multirow{3}{*}{$\mathrm{N}_{60}$} & Grain & 7.1 & 23.7 & 30.8 \\
\hline & & Straw & 1.6 & 3.2 & 4.8 \\
\hline & & Total & 8.7 & 26.9 & 35.6 \\
\hline & \multirow{3}{*}{$\mathrm{N}_{120}$} & Grain & 11.9 & 31.3 & 43.2 \\
\hline & & Straw & 3.1 & 7.7 & 10.8 \\
\hline & & Total & 15.0 & 39.0 & 54.0 \\
\hline & \multirow{3}{*}{$\mathrm{N}_{180}$} & Grain & 16.2 & 76.5 & 92.7 \\
\hline & & Straw & 5.2 & 10.7 & 15.9 \\
\hline & & Total & 21.4 & 87.2 & 108.6 \\
\hline
\end{tabular}

The $\mathbf{N}$ use efficiency in fertilizers: $\mathrm{N}$ efficiency in fertilizers was calculated taking into consideration the analytic and yield data, previously shown the according to the application rate and time. Analyzing the data, it can be concluded that the values of this indicator depend on the previous plant, on the application time of the $\mathrm{N}$ fertilizer, as well as on the fertilizer application rate.

In 1995, when the previous plant was corn (Table 5), the $\mathrm{N}$ use efficiency ranged between $17.5 \%$ and $30.6 \%$ when the fertilizers were applied in autumn and between 28.2 and 45.1 in the spring application. This year the values of the use efficiency calculated for both application times ranged between 24.6 and $40.3 \%$.

In 1996, when the previous plant was pea (Table $5)$, the $\mathrm{N}$ use efficiency in fertilizers ranged between 22.3 and $39.8 \%$ in autumn application and between 29.6 and 33.8 in spring application. The total recorded values ranged between 28.2 and $35.6 \%$.

In 1997, when the previous plant was sunflower (Table 5), the $\mathrm{N}$ use efficiency in fertilizers ranged between 35.6 and $43.5 \%$ in autumn application and between 67.2 and $72.7 \%$ in spring application. The total recorded values ranged between 59.3 and $60.3 \%$. 
Table 5: Fertilizer-N recovery (\%) of wheat from split applications of nitrogen at different levels of $\mathbf{N}$ applications in the 1994-1997 period

\begin{tabular}{|c|c|c|c|c|c|c|}
\hline Time & Previous plant & $\mathbf{N}$ & $\begin{array}{c}\text { N treatment } \\
\text { (kg/ha) }\end{array}$ & $\begin{array}{c}\text { First split } \\
\text { autumn }\end{array}$ & $\begin{array}{c}\text { Second split } \\
\text { spring } \\
\end{array}$ & Total \\
\hline \multirow{9}{*}{ 1994-1995 } & \multirow{9}{*}{ Corn } & \multirow{3}{*}{ N60 } & 13.50 & 23.25 & 23.25 & 20.00 \\
\hline & & & 4.00 & 5.00 & 5.00 & 4.66 \\
\hline & & & 17.50 & 28.25 & 28.25 & 24.66 \\
\hline & & \multirow{3}{*}{ N120 } & 20.70 & 29.87 & 29.87 & 26.80 \\
\hline & & & 5.75 & 6.25 & 6.25 & 8.16 \\
\hline & & & 26.45 & 36.12 & 36.12 & 34.96 \\
\hline & & \multirow{3}{*}{ N180 } & 22.83 & 36.58 & 36.58 & 32.00 \\
\hline & & & 7.83 & 8.50 & 8.50 & 8.27 \\
\hline & & & 30.66 & 45.08 & 45.08 & 40.27 \\
\hline \multirow{9}{*}{ 1995-1996 } & \multirow{9}{*}{ Pea } & \multirow{3}{*}{ N40 } & 21.50 & 26.66 & 26.66 & 25.00 \\
\hline & & & 3.85 & 2.96 & 2.96 & 3.25 \\
\hline & & & 22.35 & 29.62 & 29.62 & 28.25 \\
\hline & & \multirow{3}{*}{ N80 } & 23.80 & 34.20 & 34.20 & 30.80 \\
\hline & & & 6.15 & 5.18 & 5.18 & 5.50 \\
\hline & & & 29.95 & 39.38 & 39.38 & 36.30 \\
\hline & & \multirow{3}{*}{ N180 } & 33.50 & 29.12 & 29.12 & 30.56 \\
\hline & & & 6.00 & 4.62 & 4.62 & 5.08 \\
\hline & & & 39.50 & 33.78 & 33.78 & 35.66 \\
\hline \multirow{9}{*}{ 1996-1997 } & \multirow{9}{*}{$\begin{array}{l}\text { Sun- } \\
\text { flower }\end{array}$} & \multirow{3}{*}{ N60 } & 35.50 & 59.25 & 59.25 & 51.33 \\
\hline & & & 8.00 & 8.00 & 8.00 & 8.00 \\
\hline & & & 43.50 & 67.25 & 67.25 & 59.33 \\
\hline & & \multirow{3}{*}{ N120 } & 29.75 & 39.12 & 39.12 & 36.00 \\
\hline & & & 7.75 & 9.62 & 9.62 & 9.00 \\
\hline & & & 37.50 & 48.74 & 48.74 & 45.00 \\
\hline & & \multirow{3}{*}{ N180 } & 27.00 & 63.75 & 63.75 & 51.50 \\
\hline & & & 8.66 & 8.92 & 8.92 & 8.83 \\
\hline & & & 35.66 & 72.67 & 72.67 & 60.33 \\
\hline
\end{tabular}

In general (as a whole), it can be noticed, that under irrigated conditions the $\mathrm{N}$ use efficiency values, both in grains and in straws increase along with the fertilizer dose used, excepting 1997, when the previous plant was sunflower, and the values of this indicator were lower in large fertilizer doses.

\section{CONCLUSION}

The use of ${ }^{15} \mathrm{~N}$ isotope in agricultural research enables precise insight into the influence of certain technological elements on the $\mathrm{N}$ use efficiency in fertilizers.

Under brown soil conditions, the irrigated wheat crop takes different values of the $\mathrm{N}$ in fertilizers, according to the previous plant, to the application time of the fertilizers and to the application rate.

The total $\mathrm{N}$ export through the grains and straws yield to the irrigated wheat ranges between 88.5 and $211.9 \mathrm{~kg} \mathrm{~N} / \mathrm{ha}$ when the previous plant is corn, and between 93.2 and $193.9 \mathrm{~kg} \mathrm{~N} / \mathrm{ha}$ when the previous plant is pea and between 62.0 and $158.9 \mathrm{~kg} \mathrm{~N} / \mathrm{ha}$ when the previous plant is sunflower (Table 2).

The $\mathrm{N}$ amount in plants at harvest derived from fertilizers is larger in spring application, at tillering.

The $\mathrm{N}$ amount, in plants, derived from fertilizer range between 20.6 and $74.6 \mathrm{~kg} \mathrm{~N} / \mathrm{ha}$, the differences between values being registered according to the fertilizer application rate, to the application time and to the previous plant.

$\mathrm{N}$ use efficiency in fertilizers range between $17.5 \%$ and $43.5 \%$ in autumn application, at sowing time and between $28.0 \%$ and $72.6 \%$ in spring application, at tillering.

On the brown soil, under irrigated conditions, by fractionate fertilizers application- $1 / 3$ in autumn and $2 / 3$ in spring at tillering-N use efficiency in fertilizers ranges between $24.7 \%$ and $60.3 \%$, the differences between values being registered according to the application rate and to the previous plant.

\section{ACKNOWLEDGEMENTS}

The experiment was organized within a program financed by the International Atomic Energy Agency. The authors are grateful to the Professor Christian Hera for his permanent support during the experiments with ${ }^{15} \mathrm{~N}$ fertilizers. 


\section{REFERENCES}

Axman, H.-Sebastianelli, A.-Arrilaga, J. L. (1990): Sample preparation techniques of biological material for isotope analysis. Use of nuclear techniques in studies of soil-plant relationship-Training couse nr. 2 Vienna-IAEA

Ciobanu, Gh.-Hera, C. R.-Filipe, Z.-Axman, H. (1995): Posibilități de creştere a eficienței valorificării îngrăşămintelor cu azot la grâul de toamnă şi grâul de primăvară. Analele I.C.C.P.T. Fundulea, LXII. 121-138.

Hera, C. R. (1971): Soil and fertilizer nitrogen in specific plant components, with emphasis on small grains. Environmental influences and fertilizer management. "Proceedings of a research coordination meeting”. Sofia, 1-5 dec. 1969.

Hera, C. R.-Eliade, G. H.-Ghinea, L.-Popescu, A. (1984a):
Asigurarea azotului necesar culturilor agricole. Ed. Ceres Bucureşti

Hera, C. R.-Idriceanu, A.-Bologna, M. (1984b): Tehnici nucleare în agricultură. Ed. Ştiinţifică şi enciclopedică Bucureşti

Lazányi, J. (1997): Linking conventional and sustainable agriculture. In: Filep, Gy., (ed) Land Use and Soil Management. Debrecen, 68-86.

Lazányi, J. (1998): Sustainble production in Westsik's crop rotation experiment. Second Balkan Symposium. Novi Sad. 321-324.

Lazányi, J.-Vágvölgyi, S. (1999): Sunflower (Helianthus annus L.). In: Lazányi, J.-Dobránszki, J. (ed.) Agricultural Research in Nyírség Region. Nyíregyháza, 62-65. 